\title{
Pastorale begeleiding vir mense in krisistye
}

Book Title:

$U$ is 'n God wat my sien

\section{Book Cover:}

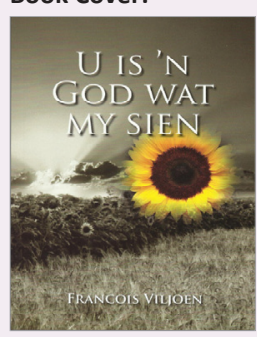

Author:

F.P. Viljoen

ISBN:

978-0-86955-200-1

\section{Publisher:}

Potchefstroom Theological

Publications, 2012, R90.00

*Book price at time of review

\section{$\square$}

Review Title:

Pastorale begeleiding vir

mense in krisistye

Reviewer:

Friedrich W. de Wet ${ }^{1}$

\section{Affiliation:}

${ }^{1}$ Practical Theology, North-West University,

South Africa

Email:

fritz.dewet@nwu.ac.za

Postal address:

PO Box 19120, Noordbrug

2522, South Africa

How to cite this book review:

De Wet, F.W., 2013,

'Pastorale begeleiding vir mense in krisistye', In die Skriflig/In Luce Verbi 47(1), Art. \#708, 1 page. http:// dx.doi.org/10.4102/ids. v47i1.708

\section{Read online:}

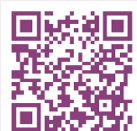

Die goed versorgde teks van $U$ is ' $n$ God wat my sien is een van die eerste voorbeelde van die nuwe reeks stigtelike boeke wat deur Potchefstroomse Teologiese Publikasies (PTP) uitgegee word. Hierdie uitgewer het onlangs besluit om voortaan manuskripte wat vir publikasie oorweeg word in drie kategorieë te onderskei, naamlik vakkundige boeke, populêr-wetenskaplike literatuur en stigtelike boeke. Waar PTP voorheen veral op die uitgee van vakwetenskaplike boeke gekonsentreer het, is dit goeie nuus dat daar nou ruimte geskep word vir die uitgee van meer populêre literatuur. In ons samelewing en kerklike lewe is 'n duidelike behoefte aan materiaal wat vanuit 'n weldeurdagte, gereformeerde vertrekpunt bydraes lewer ter toerusting van Christene vir hulle dienswerk in hierdie wêreld. Eweneens is die behoefte ook daar ten opsigte van leesstof wat troosryke ankers bied vir mense wat met ingrypende krisisse in hulle daaglikse lewens te doen kry.

$U$ is ' $n$ God wat my sien kom uit die pen van 'n skrywer wat duidelik kundig is ten opsigte van die pastorale begeleiding van mense wat met geloofsworsteling in krisistye te doen het. Die manuskrip is in die vorm van kort oordenkings geskryf. Dit dek sleuteltekste uit die Ou en Nuwe Testament wat met bewoënheid op krisissituasies gerig word. Dit het te doen met dié soort krisissituasies waarin gelowiges geneig is om met vrae te begin worstel rondom die teenwoordigheid en doel van God in ons lewens. Die skrywer het die vermoë om telkens 'n sentrale beeldryke gedagte te ontplooi op 'n wyse wat vir mense in nood 'n helder waarheid voor oë kan stel; 'n helder, ongekompliseerde waarheid waaraan hulle kinderlik kan vashou. Die oordenkings word deurgaans volgens ' $n$ trinitariese patroon ontplooi. Volgens hierdie patroon word die soekende, worstelende gelowiges se begin, voortgang en voleinding voortdurend in die drie-enige God se getroue handelings geanker.

Die publikasie sal van waarde wees vir predikante, ouderlinge, diakens en pastorale beraders wat in die krisisfase van 'n geloofsbeproewing troosryke en Skrifgetroue grepe aan mense in nood wil bedien. Dit sou ook as 'n oordenkingboek geskenk kon word aan mense wat deur 'n beproewingstyd gaan en ongekompliseerde ankerpunte vir hulle ontstelde gees nodig het. Die skrywer het 'n gebruikersvriendelike gids aan die einde van die boek ingesluit waarin elke oordenking gerangskik word volgens die bepaalde noodsituasie waarop dit veral betrekking het. Hierdie situasies sluit onder andere die volgende in: As mense jou teleurstel; As jy weerstand ervaar en jou geloof beproef word; As jy God se bestiering nie verstaan nie; As jy 'n onseker toekoms moet ingaan en groot verantwoordelikhede moet dra; As iemand verswak of sterf; As jy geestelik uitgeput is.

Hierdie publikasie word van harte aanbeveel en sal beslis tot geloofsversterking kan dien vir mense wat deur diep waters gaan. 